\title{
Analyzing the Implications of Climate Data on the Rainfall Frequency Spectrum: Case Study of Knoxville, Tennessee and Surrounding Region
}

Linda Sylvester Olufemi Omitaomu Esther Parish

September 2016 


\title{
DOCUMENT AVAILABILITY
}

Reports produced after January 1, 1996, are generally available free via US Department of Energy (DOE) SciTech Connect.

Website http://www.osti.gov/scitech/

Reports produced before January 1, 1996, may be purchased by members of the public from the following source:

\author{
National Technical Information Service \\ 5285 Port Royal Road \\ Springfield, VA 22161 \\ Telephone 703-605-6000 (1-800-553-6847) \\ TDD 703-487-4639 \\ Fax 703-605-6900 \\ E-mail info@ntis.gov \\ Website http://www.ntis.gov/help/ordermethods.aspx
}

Reports are available to DOE employees, DOE contractors, Energy Technology Data Exchange representatives, and International Nuclear Information System representatives from the following source:

Office of Scientific and Technical Information

PO Box 62

Oak Ridge, TN 37831

Telephone 865-576-8401

Fax 865-576-5728

E-mail reports@osti.gov

Website http://www.osti.gov/contact.html

This report was prepared as an account of work sponsored by an agency of the United States Government. Neither the United States Government nor any agency thereof, nor any of their employees, makes any warranty, express or implied, or assumes any legal liability or responsibility for the accuracy, completeness, or usefulness of any information, apparatus, product, or process disclosed, or represents that its use would not infringe privately owned rights. Reference herein to any specific commercial product, process, or service by trade name, trademark, manufacturer, or otherwise, does not necessarily constitute or imply its endorsement, recommendation, or favoring by the United States Government or any agency thereof. The views and opinions of authors expressed herein do not necessarily state or reflect those of the United States Government or any agency thereof. 
Computational Sciences and Engineering Division Geographic Information Science and Technology Group

\title{
Analyzing the Implications of Climate Data on the Rainfall Frequency Spectrum: Case Study of Knoxville, Tennessee and Surrounding Region
}

\author{
Linda Sylvester \\ Olufemi Omitaomu \\ Esther Parish
}

Date Published:

September 2016

\author{
Prepared by \\ OAK RIDGE NATIONAL LABORATORY \\ Oak Ridge, TN 37831-6283 \\ managed by \\ UT-BATTELLE, LLC \\ for the \\ US DEPARTMENT OF ENERGY \\ under contract DE-AC05-00OR22725
}





\section{CONTENTS}

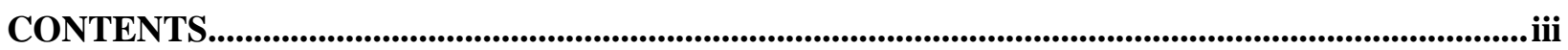

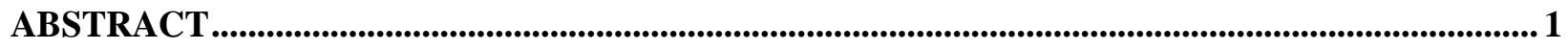

1. Background, Introduction, and Methodology ...................................................................................... 1

1.1 Background ........................................................................................................................................ 1

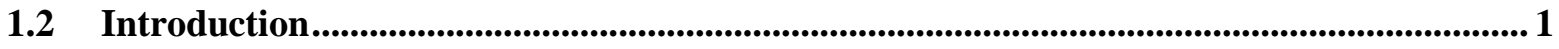

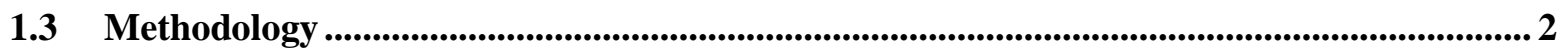

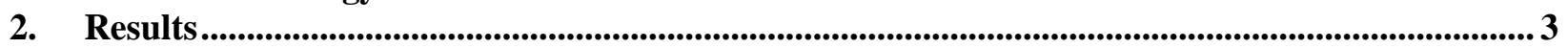

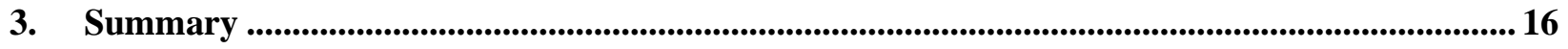




\begin{abstract}
Modeled daily precipitation values are used to determine changes in percentile rainfall event depths, for planning and mitigation of stormwater runoff, over past (1980-2005) and future (2025-2050) periods for Knoxville, Tennessee and the surrounding area.
\end{abstract}

\title{
1. Background, Introduction, and Methodology
}

\subsection{Background}

Oak Ridge National Laboratory (ORNL) and the City of Knoxville, Tennessee have partnered to work on a Laboratory Directed Research and Development (LDRD) project towards investigating climate change, mitigation, and adaptation measures in mid-sized cities. One project the city of Knoxville indicated interest in was determining the best locations for installing green infrastructure to promote precipitation infiltration and possibly help reduce future flooding. The amount of precipitation that needs to be diverted from becoming runoff, either through infiltration, increased evapotranspiration, or capture, is often determined by a defined percentile precipitation event or rainfall frequency spectrum. This work explores the use of daily gridded modeled precipitation values over past (1980-2005) and future (20252050) periods to determine possible changes in the rainfall frequency spectrum to adequately prepare green infrastructure installations.

\subsection{Introduction}

Precipitation falling on impervious surfaces and in developed areas creates increased runoff and pollutant loads compared to runoff from vegetated or permeable surface environments. Overall increases in runoff volume and peak discharge can lead to an increase in flooding, stream channel erosion, and decreased health of aquatic ecosystems. Government requirements are created and implemented throughout communities to mitigate these negative effects. Methods of capturing the water, slowing the water down, and encouraging rainfall infiltration are suggested. Green infrastructure installations, such as rain barrels, permeable pavers, and green spaces, tree plantings, and rain gardens can decrease the effects of impervious surfaces to precipitation runoff.

Implementing stormwater runoff requirements often begins with determining how much water falls during a local rainfall event. The objective is to negate, or decrease, the amount of water that becomes runoff. Rainfall Frequency Spectrum (RFS) curves allows for a visual examination of the distribution of local rainfall events. Through the use of these curves, green infrastructure can be designed for a specific amount of water or a specific percentile storm event.

Knoxville, Tennessee (within Knox County) has an official NOAA (National Oceanic and Atmospheric Administration) station located at McGhee-Tyson Airport as well as several city rainfall monitoring stations. The data from this variety of stations help to understand the spatial variation of rainfall events ${ }^{1}$. The use of just one of these stations to determine the local RFS curve would not be indicative of rainfall patterns and amounts that occur across the city and county boundaries and local watersheds. The use of a gridded dataset that covers the area of interest may give a better indication of rainfall amounts and patterns. Therefore, the use of gridded climate model results was used to determine local RFS curves for both past (1980-2005) and future (2025-2050) periods.

${ }^{1}$ http://www.knoxvilletn.gov/government/city_departments_offices/engineering/stormwater_engineering_division/ra infall_data/ 
Ten climate models were dynamically and statistically downscaled to a $1 \mathrm{~km}$ gridded resolution by ORNL. The ten models that were used are summarized in Table 1 . The models summarized precipitation data for the past period of 1980-2005 and the future period of 2025-2050 and reported values at the daily scale ${ }^{2}$. The climate models were clipped to the area of interest, which in this case is the HUC 12 watersheds (representing the hydrologic unit code of 12 digits) that cover Knox County, Tennessee.

\begin{tabular}{|c|c|c|c|c|c|c|c|c|c|c|}
\hline \multirow[t]{2}{*}{ Model } & \multirow[t]{2}{*}{ Center } & \multicolumn{7}{|c|}{ Model Components } & \multirow{2}{*}{$\begin{array}{l}\text { Atmospheric } \\
\text { Resolution }\end{array}$} & \multirow{2}{*}{$\begin{array}{l}\text { Vertical } \\
\text { levels in } \\
\text { atmosphere }\end{array}$} \\
\hline & & 官 & $\begin{array}{l}\overline{0} \\
\frac{0}{8} \\
\frac{8}{4}\end{array}$ & 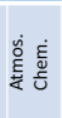 & 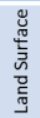 & 气్๊ & 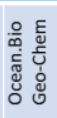 & $\frac{\Xi}{\Xi}$ & & \\
\hline ACCESS & $\begin{array}{l}\text { Commonwealth Scientific and Industrial Research } \\
\text { Organization and Bureau of Meteorology, Australia }\end{array}$ & - & • & & • & • & & - & $1.25 \times 1.88$ & 38 \\
\hline BCC-CSM & $\begin{array}{l}\text { Beijing Climate Center, China Meteorological } \\
\text { Administration }\end{array}$ & - & • & & - & - & - & - & $2.79 \times 2.81$ & 26 \\
\hline CCSM4 & National Center for Atmospheric Research, USA & • & • & & • & • & & • & $0.94 \times 1.25$ & 26 \\
\hline CMCC-CM & $\begin{array}{l}\text { Centro Euro-Mediterraneo per I Cambiamenti } \\
\text { Climatici }\end{array}$ & - & • & & & • & & - & $0.75 \times 0.75$ & 31 \\
\hline FGOALS & $\begin{array}{l}\text { LASG, Institute of Atmospheric Physics, } \\
\text { Chinese Academy of Sciences }\end{array}$ & - & • & & - & - & - & - & $1.66 \times 2.81$ & 26 \\
\hline GFDL-ESM2M & $\begin{array}{l}\text { NOAA Geophysical Fluid Dynamics } \\
\text { Laboratory, USA }\end{array}$ & - & • & & - & - & - & - & $2.02 \times 2.5$ & 48 \\
\hline IPSL-CM5A-LR & Institut Pierre Simon Laplace, France & - & • & & • & - & - & • & $1.89 \times 3.75$ & 39 \\
\hline MPI-ESM-MR & Max Planck Institute for Meteorology, Germany & • & • & & - & • & - & • & $1.87 \times 1.88$ & 95 \\
\hline MRI-CGCM3 & Meteorological Research Institute, Japan & • & • & & • & • & & - & $1.12 \times 1.13$ & 48 \\
\hline NorESM1-M & Norwegian Climate Center, Norway & • & • & - & • & - & & - & $1.89 \times 2.5$ & 26 \\
\hline
\end{tabular}

The goal of this particular study was to determine the RFS curves for the upper percentiles (75-95\%) of daily storm events for the area surrounding Knoxville, TN with the use of gridded modeled climate data for the past (1980-2005) and future (2025-2050) periods.

\subsection{Methodology}

The Environmental Protection Agency (EPA) provides guidance ${ }^{3}$, on how to calculate and create an RFS, and summarizes the procedures outlined in the guide, "Managing Stormwater in Your Community"4. Daily values of at least 30 years of data are recommended for the determination of a specific percentile event. ORNL's available $1 \mathrm{~km}$ gridded downscaled modeled data is already at the daily temporal resolution and covers 25 years, for both the past and future datasets. Small daily precipitation values $(<0.1$ inches) are to be removed from the data set, as these events generally do not cause runoff. Runoff is rarely created in those small precipitation events due to rainfall loss through interception, depression storage, and infiltration ${ }^{3}$.

${ }^{2}$ For more information on the summary model data please see Sylvester, L. M. et al. (2016). Processing and Monthly Summaries of Downscaled Climate Data for Knoxville, Tennessee and Surrounding Region. Technical Report ORNL/TM-2016/486. Oak Ridge National Laboratory.

${ }^{3}$ USEPA. (2009). Technical Guidance on Implementing the Stormwater Runoff Requirements for Federal Projects under Section 438 of the Energy Independence and Security Act (No. EPA 841-B-09-001).

${ }^{4}$ Hirschman, D. J., \& Kosco, J. (2008). Managing Stormwater in Your Community: A Guide for Building an Effective Post-Construction Program (No. EPA 833-R-08-001). Center for Watershed Protection. 
In a Linux environment, the daily events ( $>0.1$ ") for each grid cell were ranked for the entire past or future time period. The result is a single raster with a unique value for each raster grid cell. For example, a raster of the $95^{\text {th }}$ percentile is created where each grid cell contains the precipitation value that is greater than $95 \%$ of all precipitation values that occurred in that grid cell during the period of interest. Through the use of RStudio, the range of values for the area of coverage is determined and the mean value of all cells within the area is reported as the overall $95^{\text {th }}$ percentile event.

\section{RESULTS}

Graphs of the results for each model (Figure 1-10) showing past (1980-2005) and future (2025-2050) time periods illustrate the overall daily precipitation for each event percentile between the $75^{\text {th }}-95^{\text {th }}$ percentiles. These graphs comprise the RFS curves. The past values indicate the mean precipitation value for the watersheds covering Knox County. It takes into account each cell for the area of interest and averages them. The solid line on each of the charts indicates the past precipitation events and the dashed line represents the modeled future precipitation events. The shaded area indicates the low and high values that occurred in the grid for the area of interest for that percentile event. Precipitation event depths are in inches.

All of the models indicate an increasing amount of precipitation for each event percentile except for the FGOALS model which indicates the precipitation values for each percentile event will stay at a similar level or decrease slightly (Figure 5). The MPI model shows the greatest shift between past and future events (Figure 8). Table 2 shows the values across all models for the precipitation event depths while Table 3 shows the numerical difference between past and future for all of the climate models and the average. The $95^{\text {th }}$ percentile shows the largest increase between past and future events.

While the average value for each raster gives an overall indication of the percentile precipitation amount, it also is helpful to view the individual cell values and their distribution throughout the study area. Maps (Figure 11-12) which illustrate the average rainfall depth, for each individual cell at the $85^{\text {th }}$ percentile, indicate the precipitation amounts for the northwestern parts of the study area will be greater than other sections of the study area for both the past and future periods. 


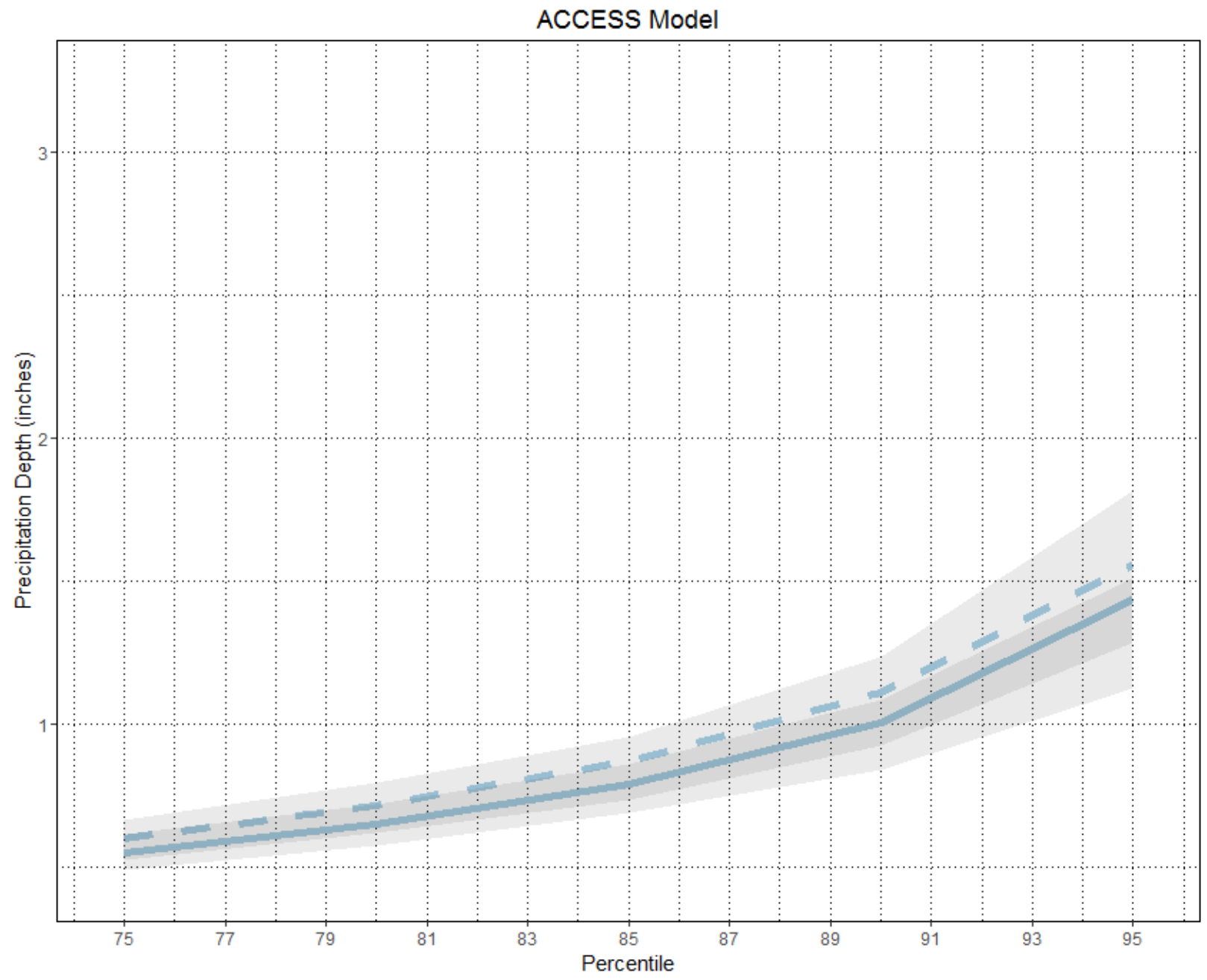

Figure 1: ACCESS Climate Model for Rainfall Frequency Spectrum values of precipitation events for the area of Knoxville, TN. Solid line indicates the mean past (1980-2005) event, dashed line indicates the mean future (2025-2050) event, and the shaded areas indicates the largest and smallest event values occurring within the region of interest. 


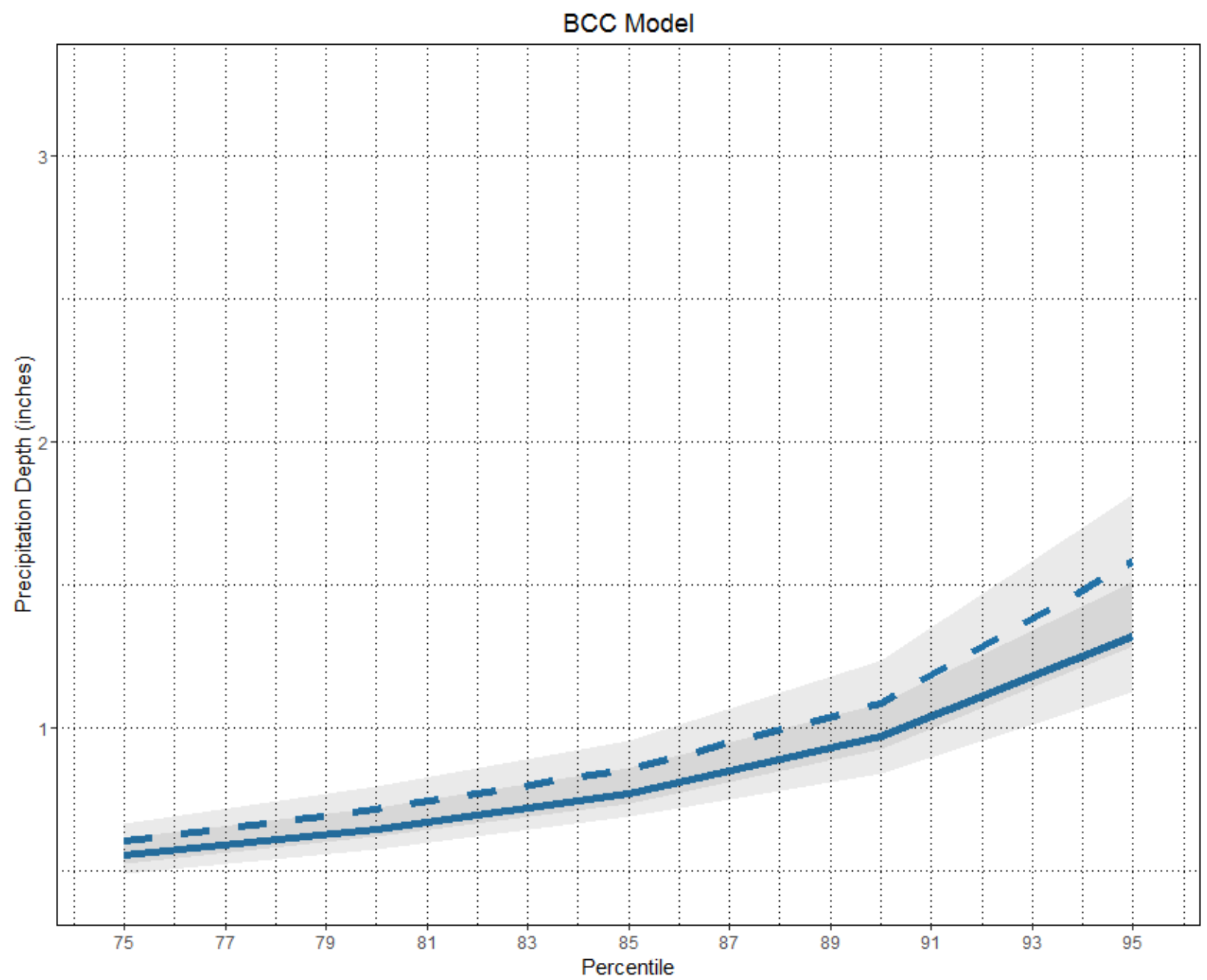

Figure 2: BCC Climate Model for Rainfall Frequency Spectrum values of precipitation events for the area of Knoxville, TN. Solid line indicates the mean past (1980-2005) event, dashed line indicates the mean future (2025-2050) event, and the shaded areas indicates the largest and smallest event values occurring within the region of interest. 


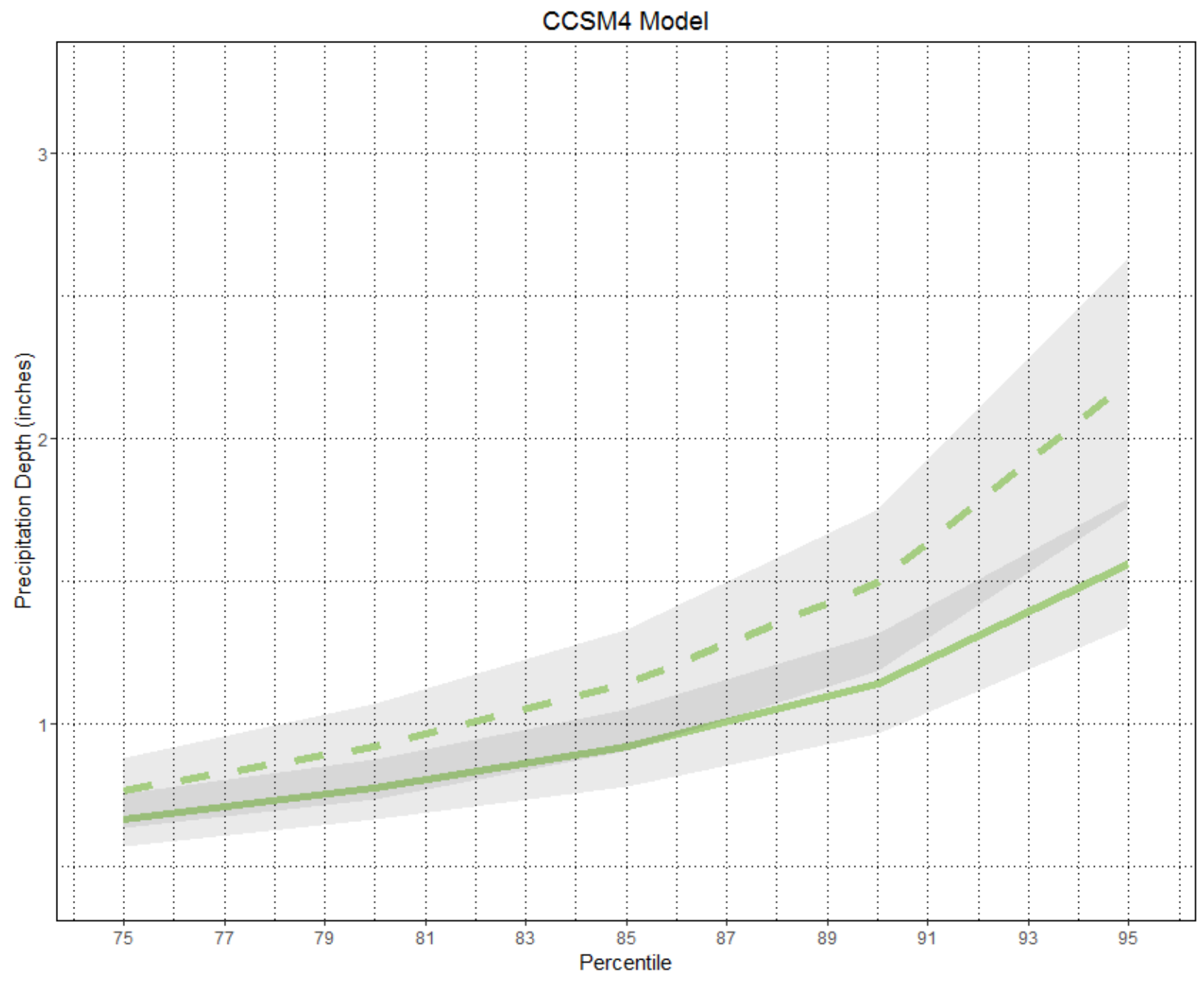

Figure 3: CCSM4 Climate Model for Rainfall Frequency Spectrum values of precipitation events for the area of Knoxville, TN. Solid line indicates the mean past (1980-2005) event, dashed line indicates the largest and smallest event values occurring within the region of interest. 


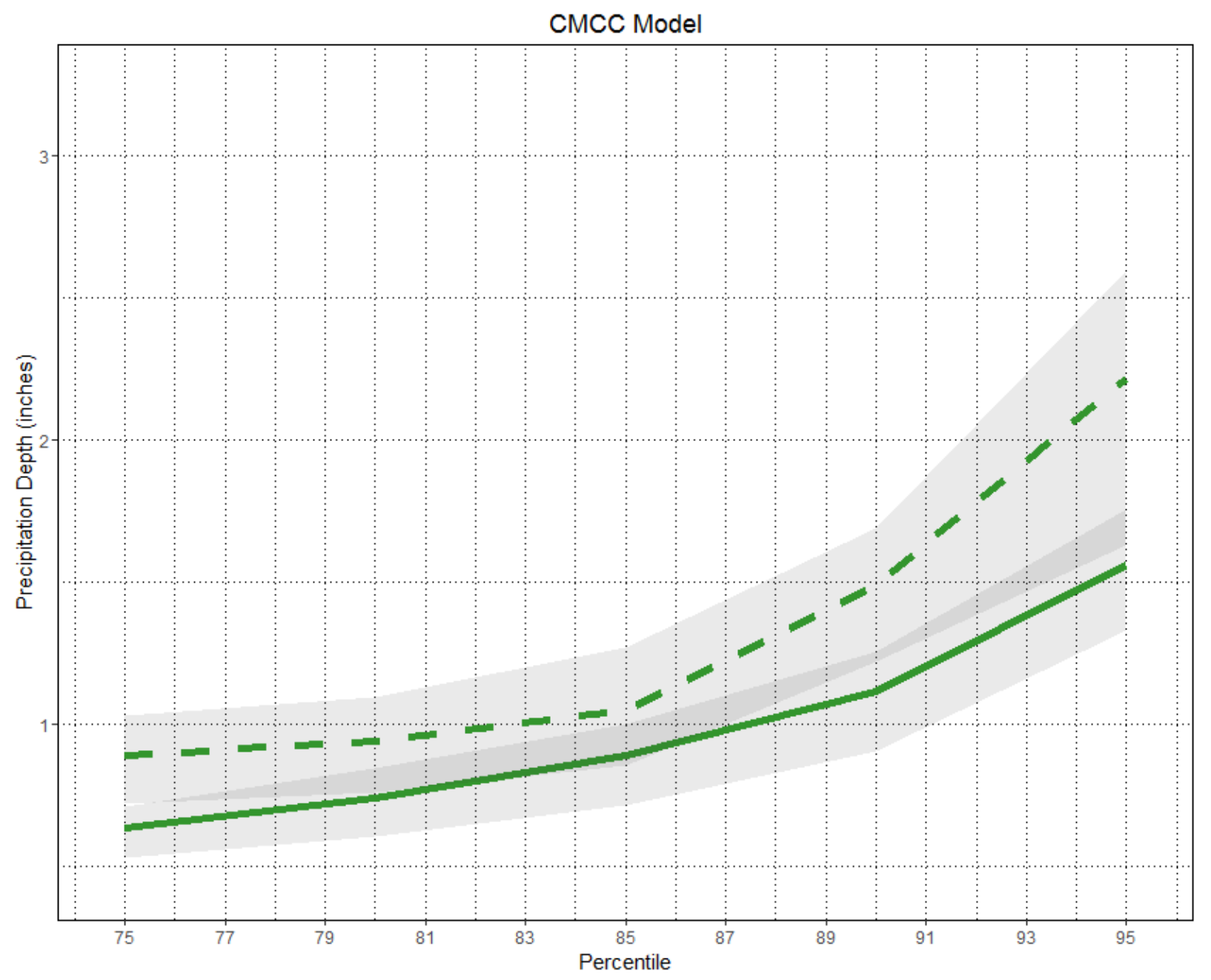

Figure 4: CMCC Climate Model for Rainfall Frequency Spectrum values of precipitation events for the area of Knoxville, TN. Solid line indicates the mean past (1980-2005) event, dashed line indicates the largest and smallest event values occurring within the region of interest. 


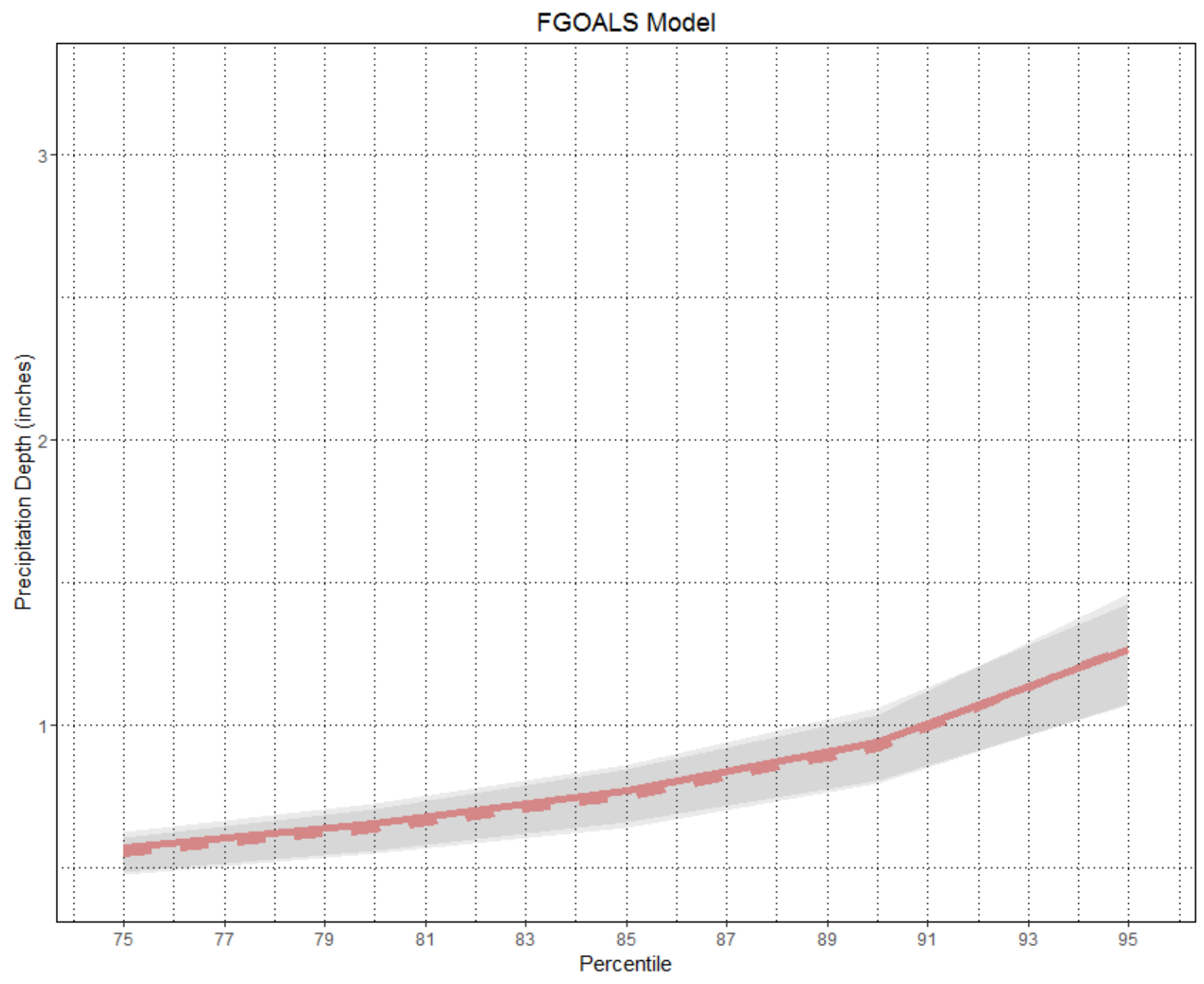

Figure 5: FGOALS Climate Model for Rainfall Frequency Spectrum values of precipitation events for the area of Knoxville, TN. Solid line indicates the mean past (1980-2005) event, dashed line indicates the largest and smallest event values occurring within the region of interest. 


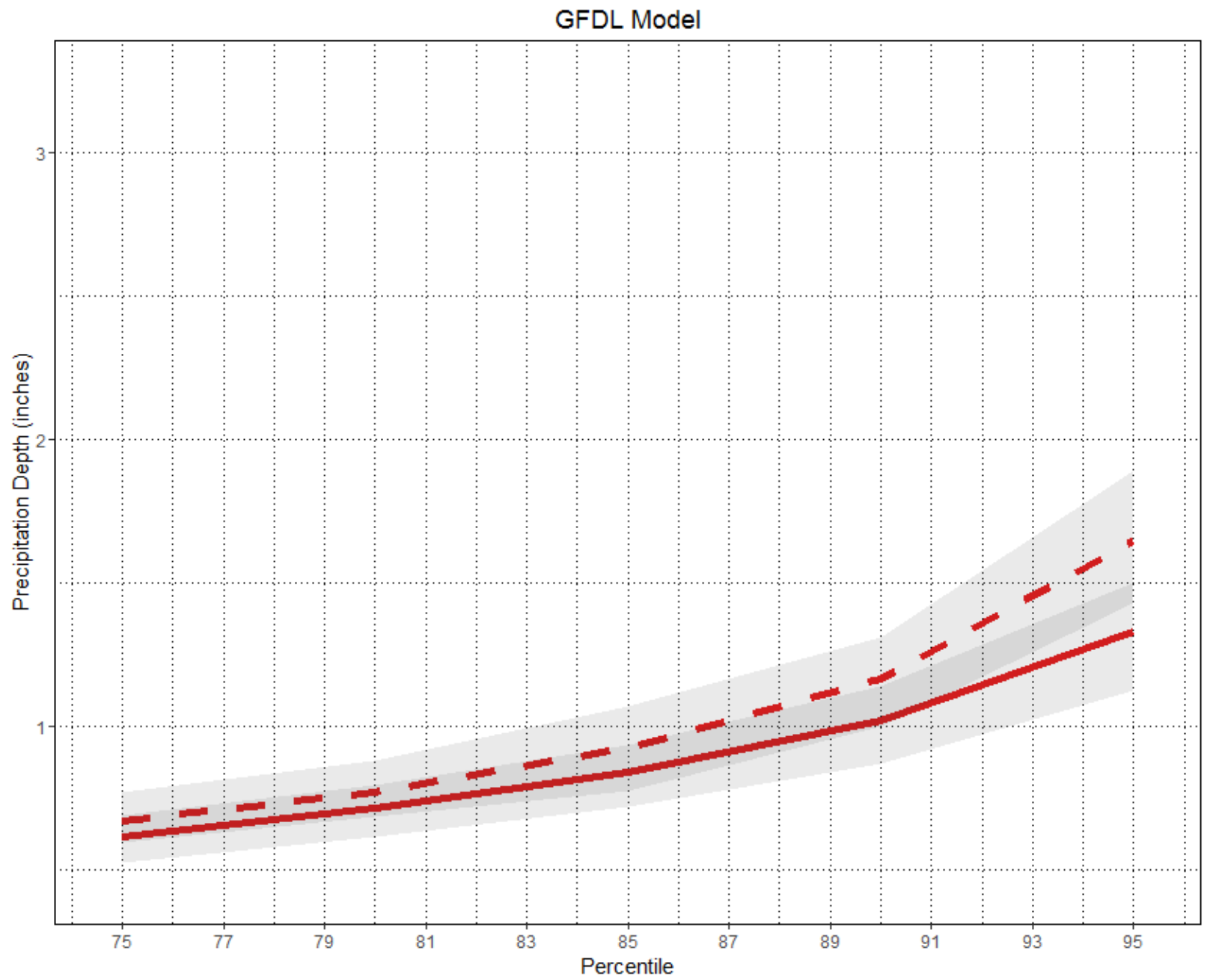

Figure 6: GFDL Climate Model for Rainfall Frequency Spectrum values of precipitation events for the area of Knoxville, TN. Solid line indicates the mean past (1980-2005) event, dashed line indicates the largest and smallest event values occurring within the region of interest. 


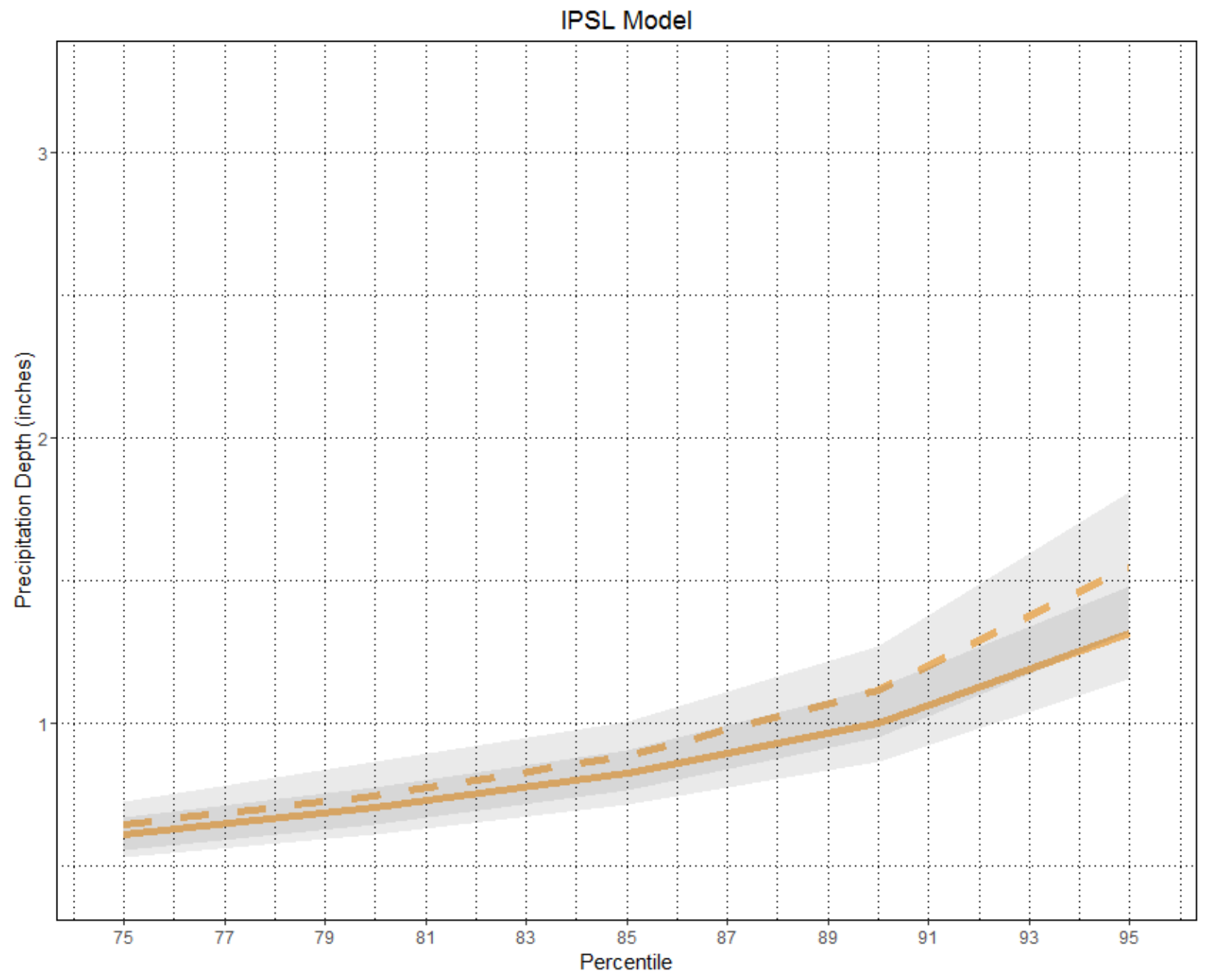

Figure 7 IPSL Climate Model for Rainfall Frequency Spectrum values of precipitation events for the area of Knoxville, TN. Solid line indicates the mean past (1980-2005) event, dashed line indicates the largest and smallest event values occurring within the region of interest. 


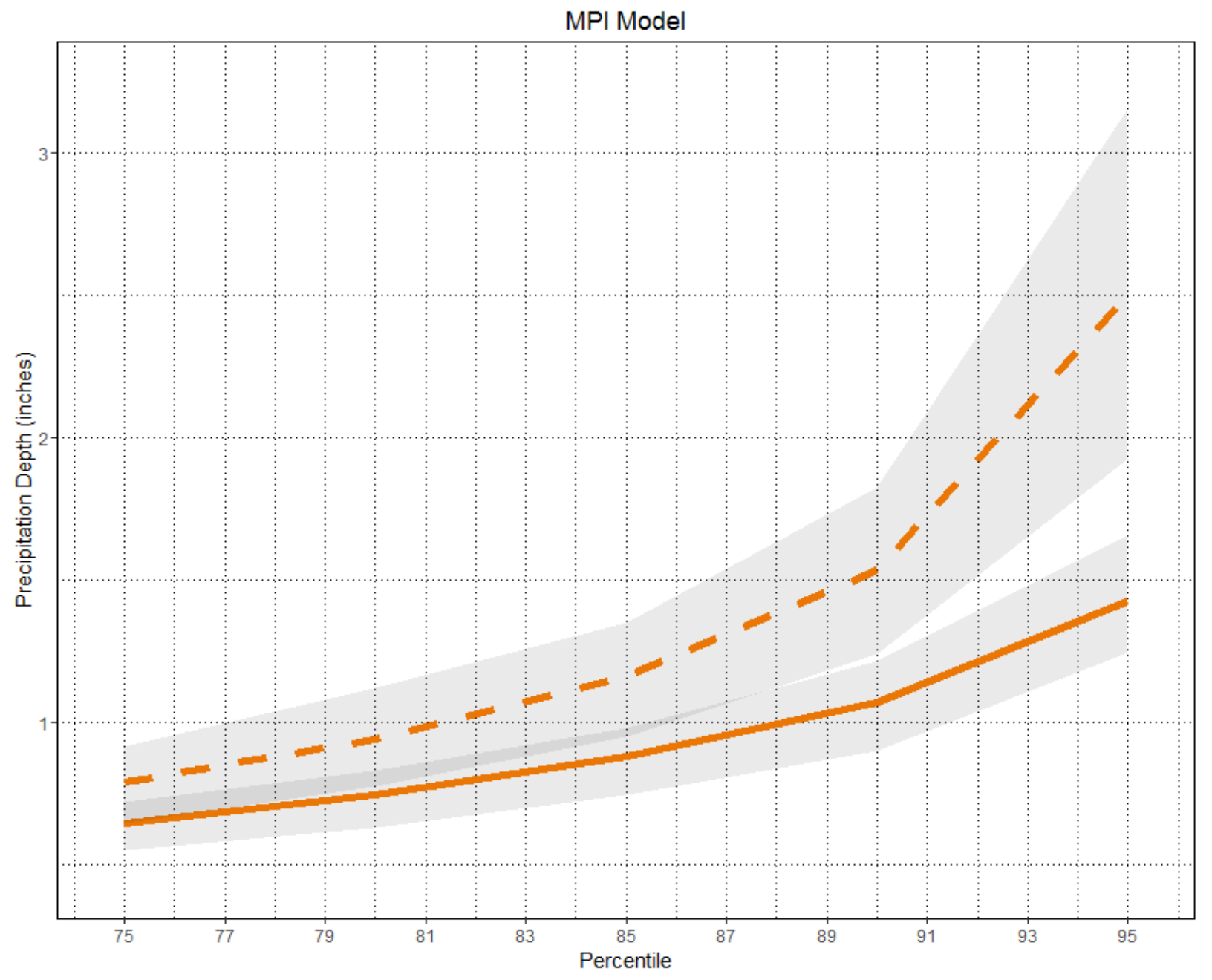

Figure 8: MPI Climate Model for Rainfall Frequency Spectrum values of precipitation events for the area of Knoxville, TN. Solid line indicates the mean past (1980-2005) event, dashed line indicates the largest and smallest event values occurring within the region of interest. 


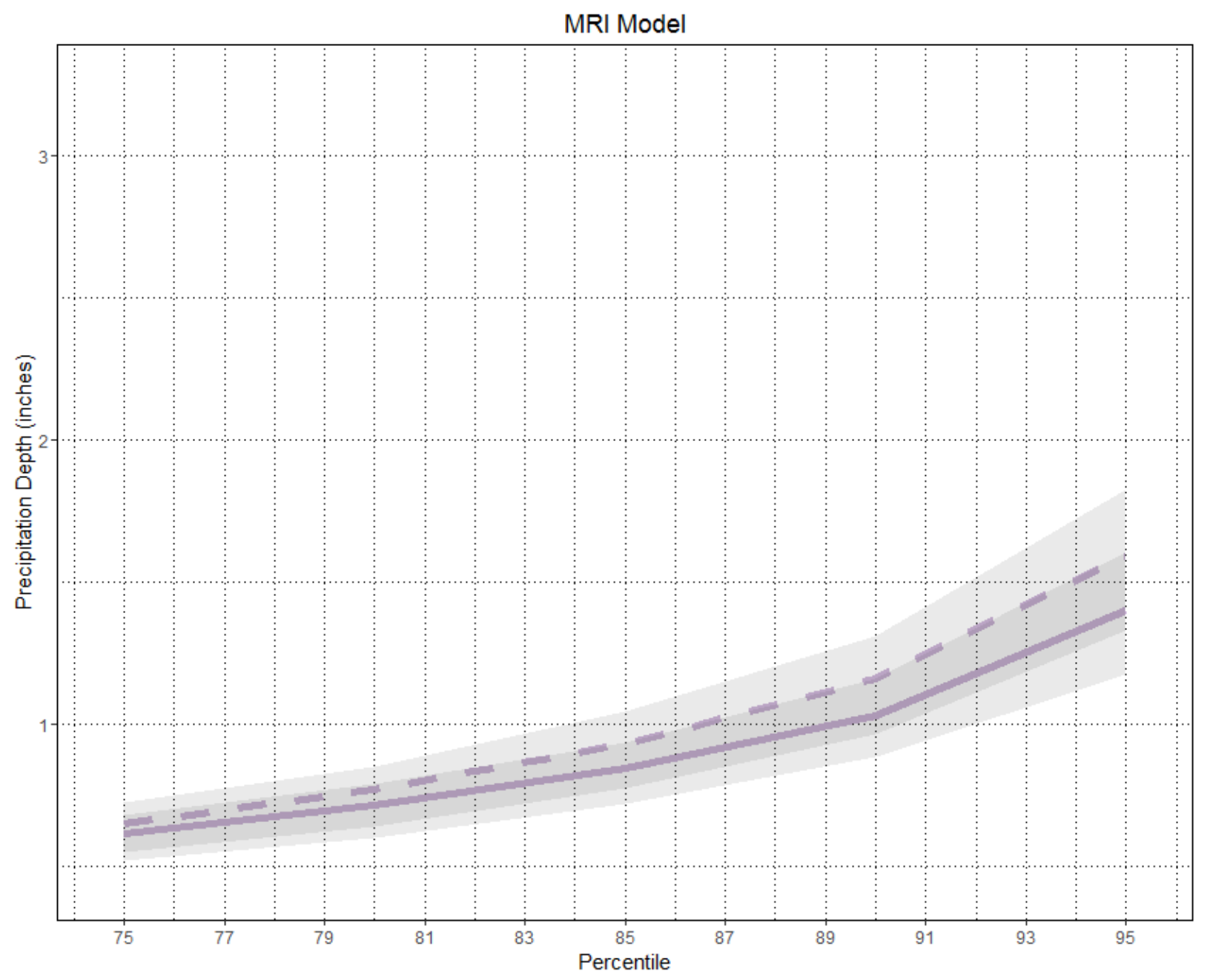

Figure 9: MRI Climate Model for Rainfall Frequency Spectrum values of precipitation events for the area of Knoxville, TN. Solid line indicates the mean past (1980-2005) event, dashed line indicates the largest and smallest event values occurring within the region of interest. 


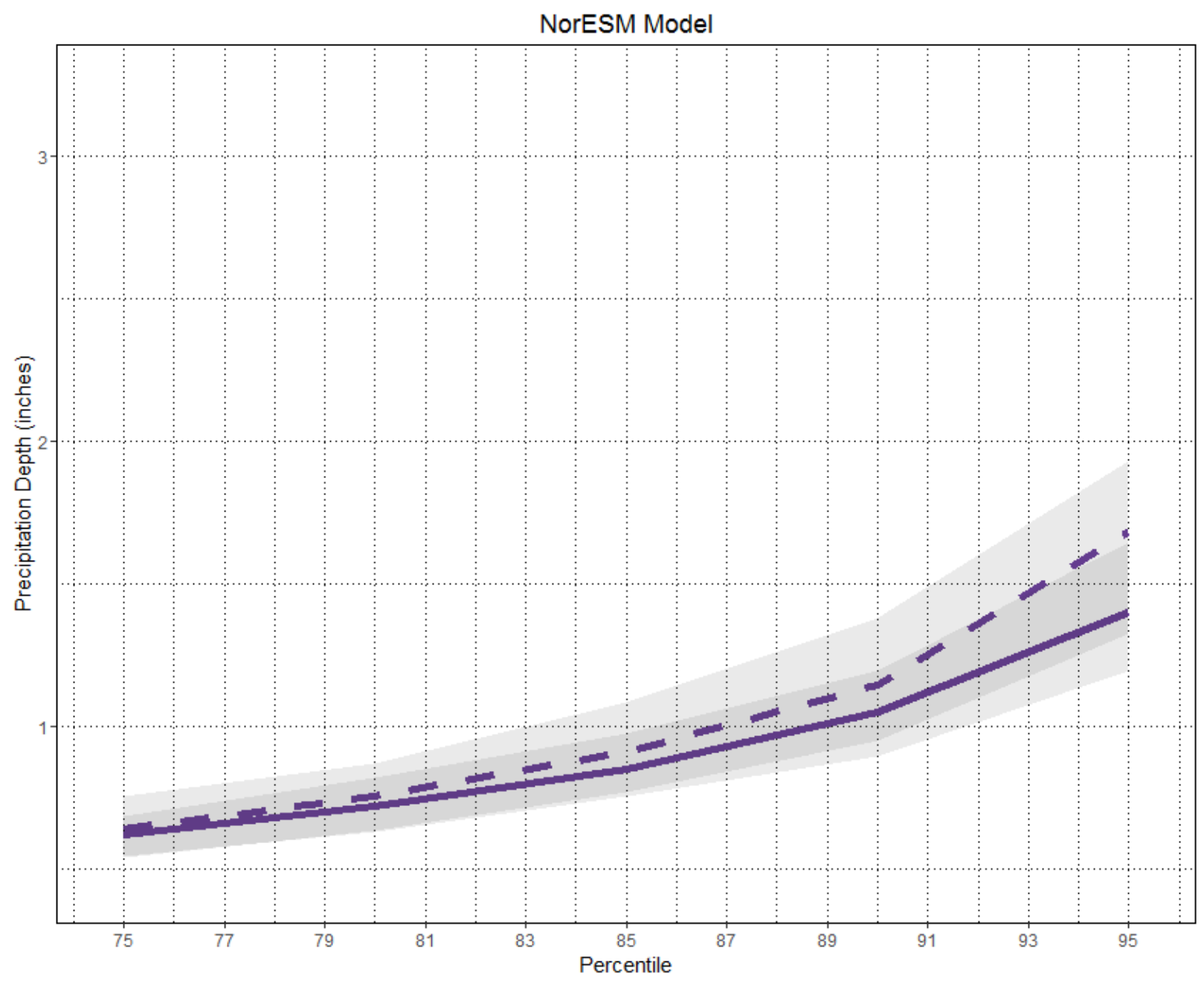

Figure 10: NorESM Climate Model for Rainfall Frequency Spectrum values of precipitation events for the area of Knoxville, TN. Solid line indicates the mean past (1980-2005) event, dashed line indicates the largest and smallest event values occurring within the region of interest. 
Table 2: $75^{\text {th }}$-95 th Rainfall Frequency Spectrum values and average value across all ten climate models for past (1980-2005) and future (2025-2050) time periods.

Model

Recent Past (1980--2005)

Event Rainfall (inches)

75th Percentile 80th Percentile 85th Percentile 90th Percentile 95th Percentile

\begin{tabular}{|c|c|c|c|c|c|c|c|c|c|c|}
\hline & 75th Percentile & 80th Percentile & 85 th Percentile & 90th Percentile & 95th Percentile & 75th Percentile & 80th Percentile & 85 th Percentile & 90th Percentile & 95th Percentile \\
\hline ACCESS & 0.55 & 0.65 & 0.79 & 1.00 & 1.43 & 0.60 & 0.71 & 0.87 & 1.11 & 1.55 \\
\hline BCC & 0.56 & 0.65 & 0.77 & 0.97 & 1.32 & 0.60 & 0.71 & 0.85 & 1.08 & 1.58 \\
\hline CCSM4 & 0.66 & 0.77 & 0.92 & 1.14 & 1.56 & 0.76 & 0.92 & 1.14 & 1.50 & 2.20 \\
\hline CMCC & 0.64 & 0.74 & 0.89 & 1.11 & 1.56 & 0.89 & 0.94 & 1.05 & 1.49 & 2.21 \\
\hline FGOALS & 0.57 & 0.66 & 0.77 & 0.94 & 1.26 & 0.55 & 0.63 & 0.75 & 0.92 & 1.27 \\
\hline GFDL & 0.62 & 0.71 & 0.84 & 1.02 & 1.33 & 0.67 & 0.77 & 0.93 & 1.16 & 1.64 \\
\hline IPSL & 0.61 & 0.70 & 0.82 & 1.00 & 1.31 & 0.64 & 0.74 & 0.89 & 1.12 & 1.54 \\
\hline MPI & 0.64 & 0.74 & 0.88 & 1.07 & 1.43 & 0.79 & 0.94 & 1.16 & 1.53 & 2.50 \\
\hline MRI & 0.61 & 0.71 & 0.84 & 1.03 & 1.40 & 0.65 & 0.77 & 0.93 & 1.16 & 1.59 \\
\hline NorESM & 0.62 & 0.72 & 0.85 & 1.05 & 1.40 & 0.64 & 0.76 & 0.91 & 1.15 & 1.68 \\
\hline Average & 0.61 & 0.71 & 0.84 & 1.03 & 1.40 & 0.68 & 0.79 & 0.95 & 1.22 & 1.78 \\
\hline
\end{tabular}

Future (2025--2050)

Event Rainfall (inches)

Table 3: Difference between past (1980-2005) and future (2025-2050) $75^{\text {th }}-95^{\text {th }}$ rainfall events for all ten climate models and their average.

\begin{tabular}{|c|c|c|c|c|c|c|}
\hline \multirow[t]{2}{*}{ Model } & \multicolumn{6}{|c|}{$\begin{array}{c}\text { Difference } \\
\text { Between Past and Future } \\
\text { Event Rainfall (inches) }\end{array}$} \\
\hline & 75th Percentile & 80th Percentile & $\underline{\text { 85th Percentile }}$ & & tile & tile \\
\hline ACCESS & 0.05 & 0.07 & 0.08 & ] & 0.10 & 0.12 \\
\hline BCC & 0.05 & 0.07 & 0.08 & & 0.12 & 0.26 \\
\hline CCSM4 & 0.10 & 0.14 & 0.22 & & 0.36 & 0.64 \\
\hline CMCC & 0.25 & 0.20 & 0.16 & & 0.38 & 0.65 \\
\hline FGOALS & -0.02 & -0.02 & -0.02 & & -0.02 & 0.01 \\
\hline GFDL & 0.05 & 0.06 & 0.09 & & 0.14 & 0.31 \\
\hline IPSL & 0.03 & 0.04 & 0.06 & 1 & 0.12 & 0.23 \\
\hline MPI & 0.15 & 0.19 & 0.28 & & 0.46 & 1.07 \\
\hline MRI & 0.04 & 0.05 & 0.08 & & 0.13 & 0.19 \\
\hline NorESM & 0.02 & 0.04 & 0.06 & & 0.10 & 0.28 \\
\hline Average & 0.07 & 0.08 & 0.11 & 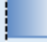 & 0.19 & 0.38 \\
\hline
\end{tabular}




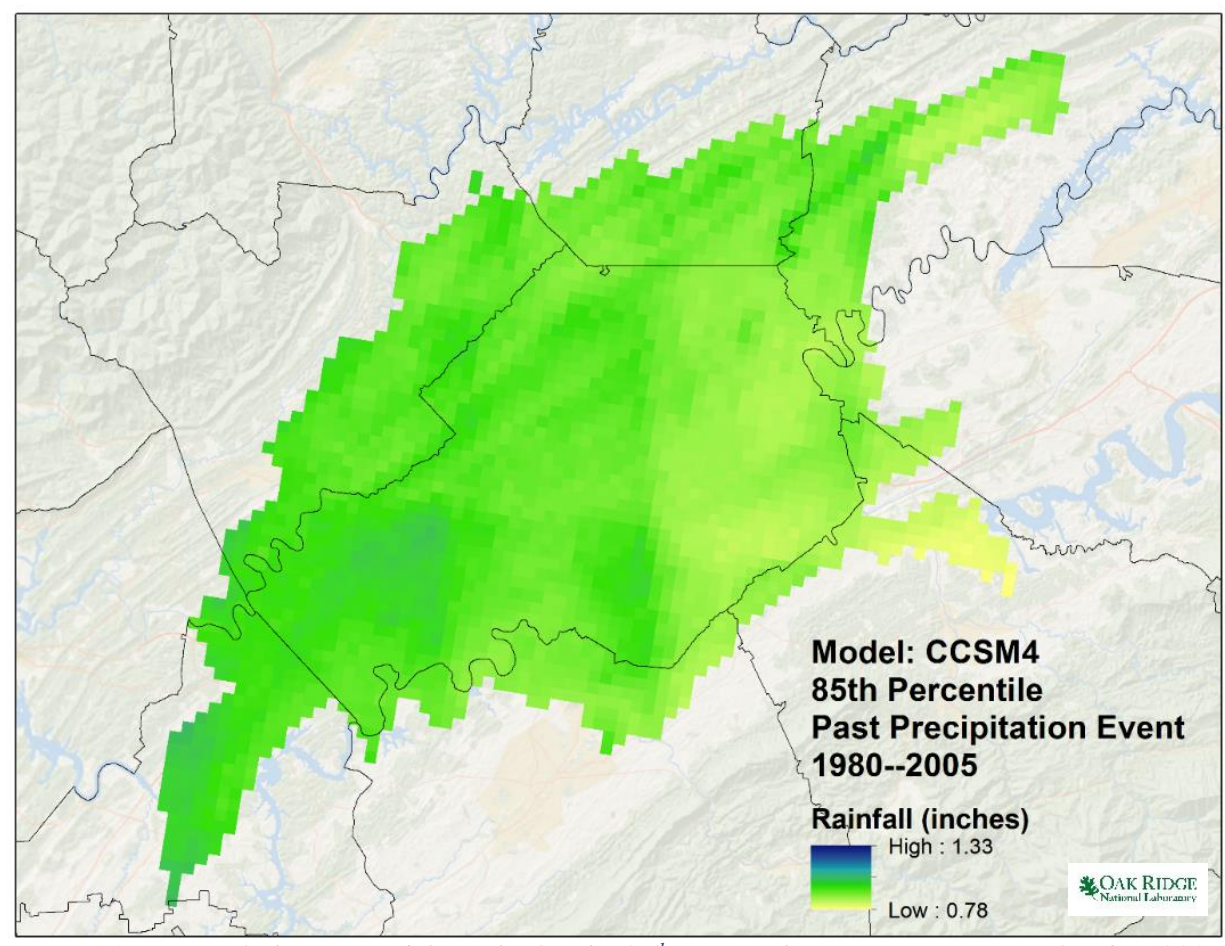

Figure 11: CCSM4 climate model results for the $85^{\text {th }}$ percentile precipitation event for the 19802005 period. Area of coverage concerns the watersheds that cross Knox County, Tennessee.

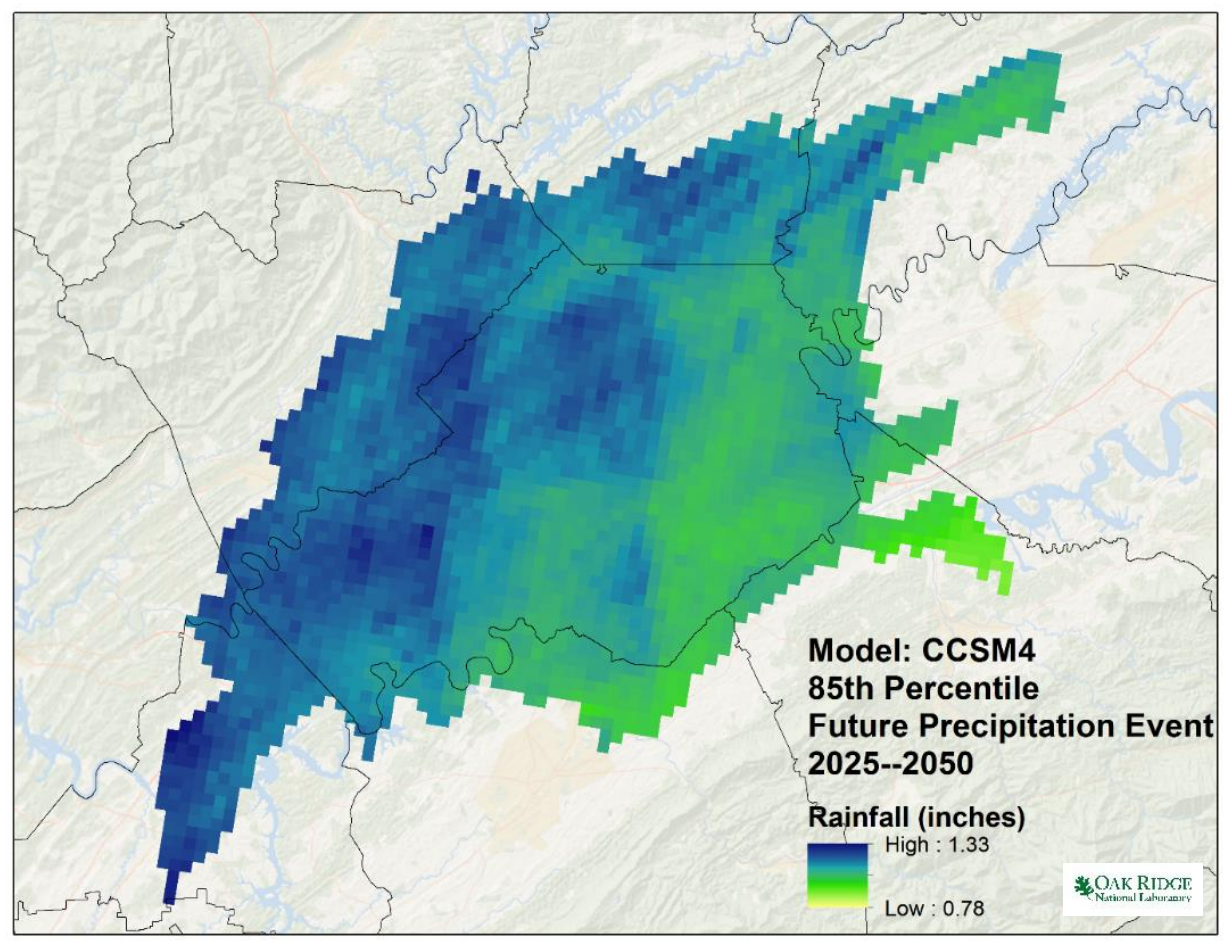

Figure 12: CCSM4 climate model results for the $85^{\text {th }}$ percentile precipitation event for the 20252050 period. Area of coverage concerns the watersheds that cross Knox County, Tennessee. 


\section{SUMMARY}

The overall trend in the RFS is that daily events beyond the $90^{\text {th }}$ percentile show the greatest increase between the difference of past and future precipitation event data. Future studies on RFS should focus on the rainfall events that are greater than $90 \%$. While few of the daily precipitation events will be in this category, the greatest increase in precipitation amounts appears to be projected to occur during the largest precipitation events. The summary graph (Figure 13) shows all of the modeled event data for both past and future time periods.

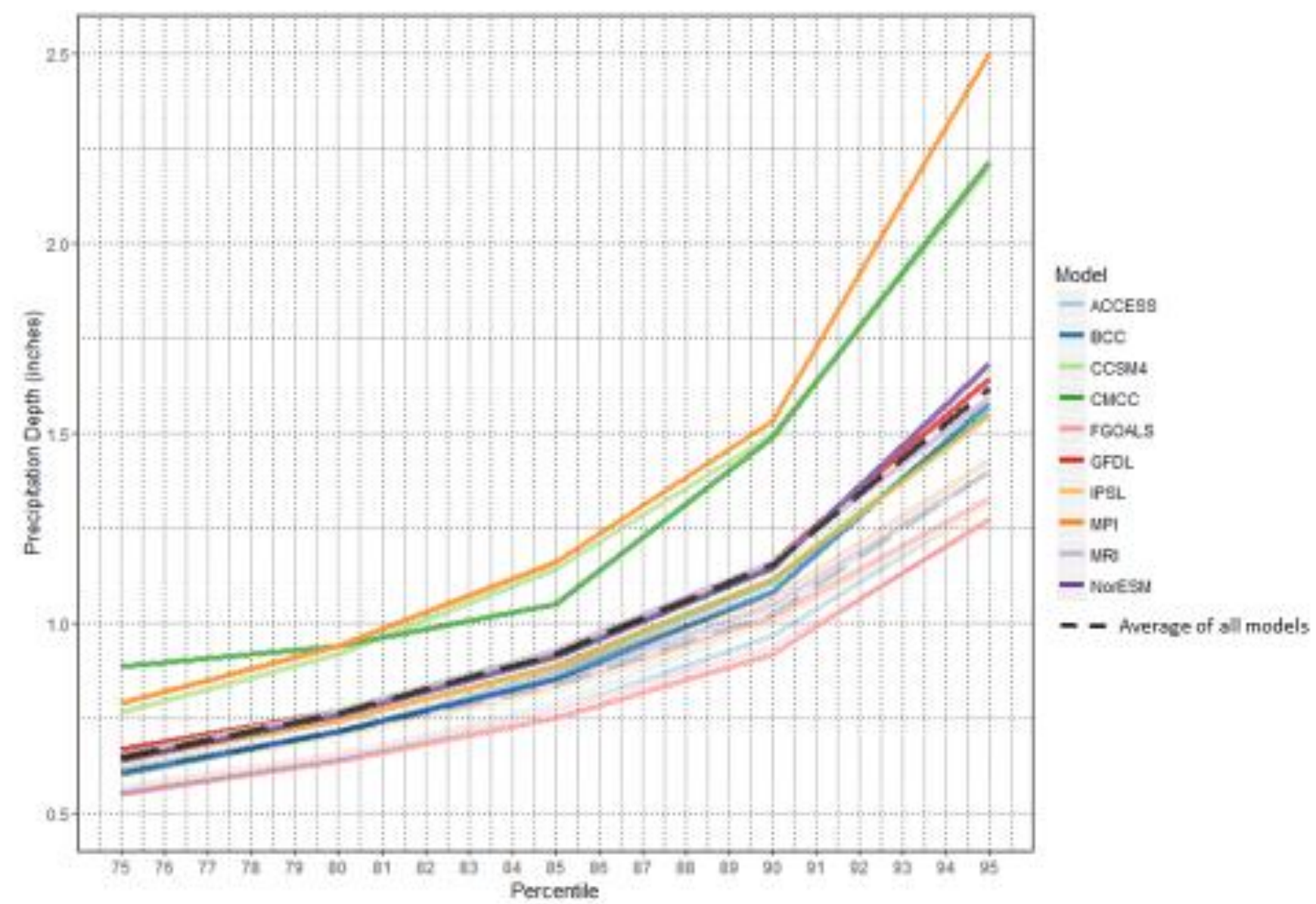

Figure 13: Climate model results for Rainfall Frequency Spectrum values of precipitation events for the area of Knoxville, TN. Faded lines indicate the mean past (1980-2005) event, color coded by each individual model. The brighter colored lines indicate the mean future (2025-2050) precipitation event, color coded by each individual climate model. The dashed lines indicate the average past and future values for all models within the region of interest. 